\title{
IKZF1/BCL6 Fusion Gene
}

National Cancer Institute

\section{Source}

National Cancer Institute. IKZF1/BCL6 Fusion Gene. NCI Thesaurus. Code C99582.

A fusion gene that results from a chromosomal translocation $t(3 ; 7)(q 27 ; p 12)$ which fuses the promoter of the IKZF1 gene near the 5' end of the BCL6 gene. This rearrangement is associated with aberrant expression of the BCL6 gene product and Bcell non-Hodgkin lymphoma. 